\title{
THOMAS LEWIS
}

Thomas Lewis was born at Cardiff on December 26, 1881. His father and mother, who were both Welsh, took a great interest in the education of their children and to this Lewis attributed his later success as a scientist. Except for one year at Clifton College, Lewis, up to the age of sixteen years, was educated entirely at home. He took little interest in book learning during these years, preferring to spend his time in the country, satisfying his innate curiosity in respect of natural objects, and his interest in outdoor sports. Before he was ten years old he had decided to become a doctor, but he apparently failed to realize the educational implications of this decision, for he failed in his London matriculation examination when he was sixteen. This failure, as one would expect, did not deter him, but goaded him to apply himself to his books.

A year later he matriculated in the first division in the University of London and never failed in any subsequent examination. A brilliant student career followed, first at Cardiff and later at University College Hospital, London. In 1905 he qualified as M.B., B.S. (London), winning a triple distinction and the University Gold Medal, and gained the D.Sc., Wales. During this time he had already shown his interest in research, for, with Swale Vincent at Cardiff, he had published a series of papers on the proteins of unstriped muscle and on the hæmolymph glands. As a student at University College Hospital he carried out some researches but stated that he achieved nothing. He was, however, meeting men of great ability such as Dale and Elliott and Noon of the Physiological Society, lunching with seniors like Starling, Bayliss, and Cushing, and it was quite clear that his interest was steadily moving in the direction of a research life.

He started work, in fact, in Starling's physiological laboratory in 1907; but in 1909 he put up his plate in Wimpole Street. This action, which suggested that he could not make up his mind whether to take up a research career or a consultant's life, was determined by the fact that opportunities for full-time research were practically non-existent to a man without private means. Lewis, though the son of a well-to-do father, was not the man to rely on parental wealth.

In 1908 Lewis met James Mackenzie. He was stirred by Mackenzie's critical attitude to medicine, and his independence of authority, under the spell of which he had fallen while in hospital. Mackenzie had a profound influence, for not only did he urge Lewis to take up research but suggested a problem, namely, the analysis of irregular cardiac actions. Lewis quickly saw that the string galvanometer, which Einthoven had recently developed, was the instrument most likely to give results in this field, and started his researches, both in the laboratory and the clinic, which added so much knowledge to the subject. Even at this stage his careful nature did not allow him completely to take the chances of a research life, so he combined hospital work and private practice with his research work. In 1910 he obtained the first of the newly created Beit Memorial Fellowships, but he did not relinquish private practice until 1916, when he was appointed a physician on the staff of the Medical Research Committee, as the Medical Research Council was then called.

He was then able to throw all his energies into research, as he had long wished to do. Even during the transitional period he achieved more than most would have done, had they given their full time to research. He published in 1911 his first book, The Mechanism of the Heart Beat, a book written for advanced students which gained in size as new knowledge, mainly from his own laboratory, was obtained, and became the "bible" of all those interested in cardiographic work. About the same time he also published two small books, namely Clinical Disorders of the Heart Beat (1912) and Clinical Electrocardiography (1913), which were written for practitioners. The character of these two books clearly indicates what Lewis always kept in mind: to seek for new knowledge and to use it for the simplification of diagnosis 
and treatment of the sick. In addition, not satisfied with the opportunities for publishing the scientific data of his work, he founded in 1909 (with Mackenzie's help) and edited a new journal, Heart.

In 1916, when Lewis was only 33 years old, he published a series of remarkable papers in the Philosophical Transactions of the Royal Society; they detailed with remarkable clarity the spread of the electrical process across the chambers of the heart, when it was beating normally and abnormally, and related the findings to normal and abnormal human electrocardiograms. These papers are models of publication, not only in the clearness of presentation but also in the beauty of the illustrations, all of which he prepared himself. (Of this mass of work, that relating to the electrocardiogram of right and left bundle branch block has alone failed to stand the test of time.) This work was outlined in his Croonian Lecture to the Royal Society in 1917, and he was elected a Fellow in 1918.

During the First World War, Lewis was asked to investigate the condition known as "Soldier's heart" (D.A.H.) which was causing a serious loss of man power in the Army. With Meakins and Parkinson he directed the clinical services of a special hospital for this purpose, first at Hampstead and later at Colchester. With his characteristic energy he tackled his new problems and defined the condition, which he renamed "effort syndrome," and devised a treatment of graduated exercises which was eminently successful. As consulting physician to the Ministry of Pensions he took the opportunity of keeping in touch with a large number of soldiers pensioned with heart trouble for a sufficient length of time to gain further knowledge of the diagnosis, prognosis, and treatment of patients suffering from real or suspected cardiac disease. He also published a paper on dermatographism presenting the evidence for the independent contractile power of the capillaries. He received the C.B.E. in 1920 and a year later was knighted for his work during the war and for the Ministry of Pensions.

The war over, Lewis took up the study of the mechanism underlying auricular flutter and fibrillation. By a series of interrelated experiments on dogs and human beings, he concluded that the mechanism was that of a wave circulating around the mouths of the great veins. It was in his view a " circus movement" similar to that already described in cold-blooded contractile tissues. This conception has been generally accepted, though some workers could not unreservedly accept it.

When he was about 43 years old, the character of his researches underwent a striking change. He had.decided that the proper subject to study was man, and henceforward he worked with man almost to the exclusion of animals. He gave up the complex technique of electrocardiography, involving animals, and turned to problems in man, using simpler techniques. He took up problems that had interested him during the war and studied the reaction of the skin vessels to injury. He obtained evidence that with all forms of injury a substance, "H substance," was liberated, which was indistinguishable from histamine, but which he refrained from calling histamine, as conclusive evidence was lacking. All this work he published in his book Blood Vessels of the Human Skin.

In 1927 he was awarded a Royal Medal by the Royal Society. In the same year work was interrupted by his first attack of coronary thrombosis; unacquainted with the recent American work on this subject he did not at first recognize the nature or the seriousness of his illness. It was with difficulty that he accepted the need for prolonged rest. The pain he suffered was intense, and this stimulated his later interest in this subject. He made an excellent recovery, but, recognizing the need for less strain he moved to the country, choosing gardening and fishing as recreations. He again set to work and continued his observations upon peripheral blood vessels, and showed that the pain of intermittent claudication was due to a chemical and physico-chemical stimulus which he called factor P: it was not identified. Evidence was also obtained which suggested that the pain of angina was due to a similar mechanism. Further work on skin tenderness led to Lewis postulating the existence of a new system of nerves which were called by him " nocifensor nerves." These researches were published in book form (Pain) in 1942. In 1941 Lewis was awarded the. Copley Medal of the Royal Society and in 1945 the Conway Evans Prize.

In addition to the study of specially selected patients, Lewis continued to see hospital patients suffering from all kinds of cardiovascular diseases. As a result of this he published two 
more books, Diseases of the Heart in 1933 and Vascular Disorders of the Limbs in 1937. They were designed for clinical use and contained much that was new.

All this time Lewis had been considering how he could foster and perpetuate such work as he was successfully accomplishing. He set himself to attract young men to his way of life and thinking, and published two books, Clinical Science, Illustrated by Personal Experience (1934) and Research in Medicine and other Addresses (1938) which gave expression to his creed. He ensured that opportunities were available for those wishing to carry out clinical research, by scholarships, grants, and by the establishment in other hospitals of departments like his own. In 1937 the financial support of his appointment was transferred to a Trust endowed by the Rockefeller Foundation. At the same time, he founded the Medical Research Society as a meeting ground for critical discussion and the promotion of friendship among those engaged in clinical research, and was its first chairman. He maintained a close contact with the Cardiac Club which was founded in 1922; and was Chairman at its first meeting in London that year. He had agreed to be chairman at the annual meeting of its successor the Cardiac Society in 1945, but wrote some little time before his death regretting that he would not be well enough to do so. When the Cardiac Society decided to start the British Heart Journal in 1939 they were pleased to have a Foreword written by him as a welcome start. In 1933 he had changed the title of his journal Heart to that of Clinical Science and passed the control of the journal into the hands of the Medical Research Society in 1938, though he remained editor till 1944.

When the Second World War broke out he tried to pursue research in relation to war needs, but could not find an opportunity. He therefore took on more teaching to free others, and carried on with his researches, but towards the end of 1944 his health broke down again (he had had a second attack of coronary thrombosis in 1935), and he died in the spring of 1945. He was buried at Llangorst Church, Llangasty, Brecon.

In such a small compass it is not possible to give more than the barest outline of his achievements. He published about 230 papers in all and wrote 12 books. He disciplined himself to write in a clear and concise style and in later life could write-swiftly and without amendment. He took the greatest care in his writings to present all the evidence, not wishing that anything should be accepted on his authority alone. As an editor he insisted on a very high standard from all his contributors. Many received their manuscripts back for revision with some dismay at the number of pencilled alterations. Those who went through them personally with him had a trying ordeal. Some complained that the individuality of the author became lost but most recognized the great improvement that came from his criticisms.

As a teacher he had the faculty of making difficult subjects clear and interesting. He always developed his story in a simple and logical manner and tried to instil into his students the power of observation and reasoning. He was interested in medical education and as late as last year he published an article in the Lancet outlining his views.

To cardiologists he will chiefly be remembered during the years up to 1935 . He was not an impressive figure in those early days. He was of medium height, spare built, active and tireless. Two characteristics arrested attention, the penetrating look of his deep blue eyes and his quiet voice. He was then in full health, working with unremitting energy year after year, for ten months on end. Problem after problem was attacked in the laboratory, information continually collected in the clinic, which gave knowledge not only to the advanced student but to those dealing with the diagnosis, prognosis, and treatment of cardiac disease. He grudged every minute not spent on his actual problems. Public holidays, committees, discussions on general scientific problems, small talk, were all disregarded if he felt they interfered with the speed of his work. He was capable of driving himself at high pressure and expected the same of his co-workers. They found the pace terrific, and knew there could be no respite till the specific problem in hand was solved or he went away for his annual holiday. Then, for two months on end, he gave the same energy and enthusiasm to watching and photographing birds. In this, as in many other aspects of his life, he received much help and encouragement from his wife (whom he married in 1916); and many will remember the beautiful photographs they saw when they visited him in his delightful home.

To work with him revealed his great characteristics, which were not always evident to those who knew him slightly. A man of contrasts, he was difficult to know well and difficult 


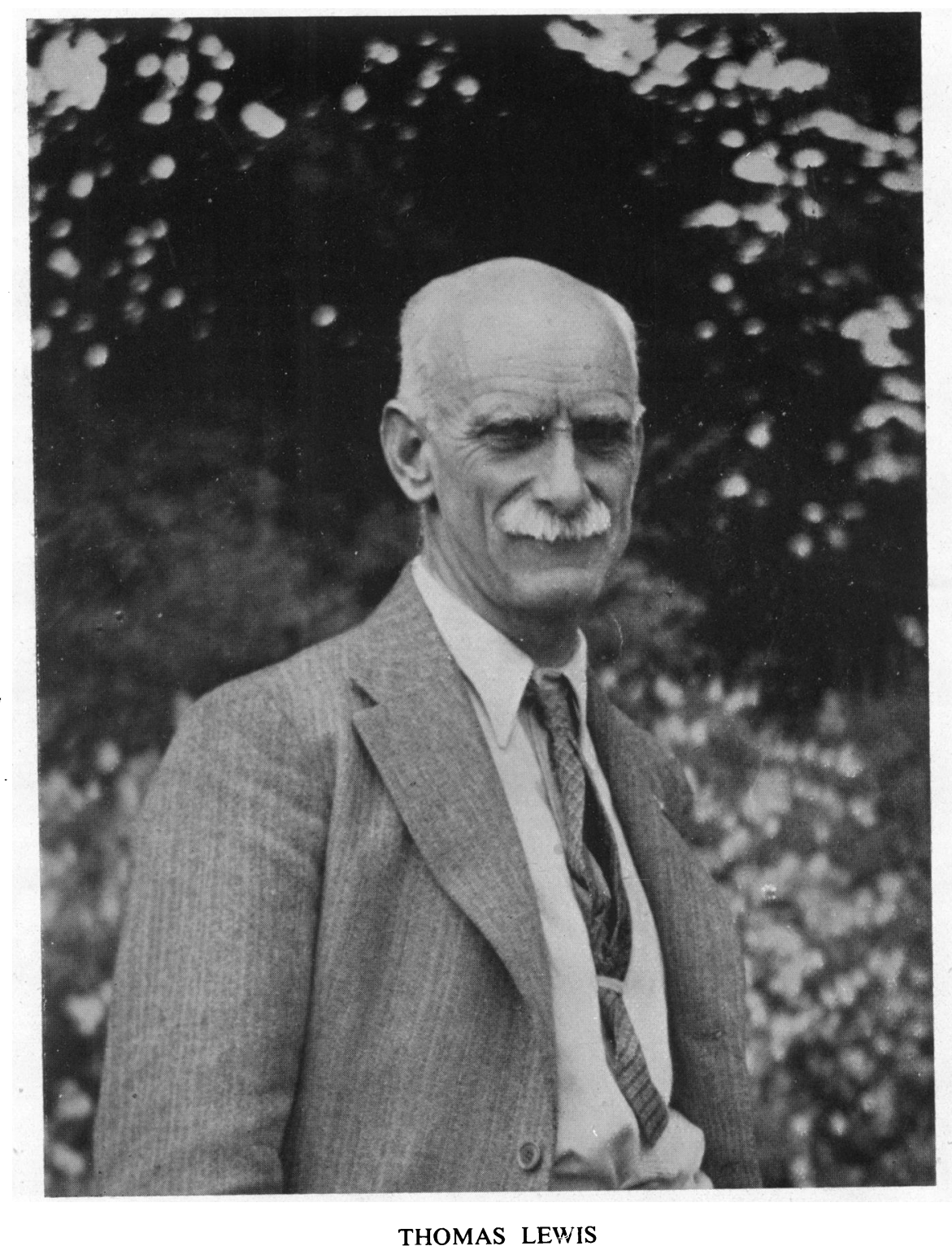


to understand. He was a humble-minded man, entirely honest, and ready to give help to all those who sincerely asked for it, and able to talk freely on many scientific subjects. He was at the same time a man of great reserve and singleness of purpose. In consequence, when he was immersed in a problem, his impatience, hardness, hatred of slipshod work, and his outspoken manner were not understood by those who did not appreciate his way of life; a sense of ruthlessness was in his work. He resented ill-formed criticism, and defended his views vigorously, but when he was convinced that proper evidence had been brought forward from the newer view, he accepted it without question, for he venerated the truth. He not only won universal admiration for his scientific achievements, but all his associates had a great personal regard for him.

In 1929 thirty-seven of his colleagues (all who had worked with him at University College up to that date) gave him a volume of their photographs and in a letter expressed their thanks for his help by teaching and example and for his many acts of kindness. This gift, arising as a spontaneous expression of their high regard for him, gave him great pleasure. Had this gift been delayed till much later, and had it been possible to include all those who had benefited by his example and teaching, it would have been an immense volume. It has fallen to few scientists to achieve so much and to have had such a profound influence upon the subjects which they have fostered.

A. N. DRURY

R. T. GRANT

Lewis can scarcely be regarded as a pupil of Mackenzie; rather he was already trained, scientifically mature, and well fitted to extend and consolidate the modern conception of cardiac disease which began in Britain early this century. Let us say that Mackenzie was passionately dissatisfied with what he could tell and what he could do for his patients, and so he bent his powerful mind to research mostly by observation. He recognized the calibre of Lewis and persuaded him that here was the opportunity for his talent. Observation was not enough, planned scientific experiment was essential, the electrocardiograph was available, and Lewis started on his course. In no hurry, patiently and steadfastly, he forgot himself in this great work on cardiac physiology, animal and human. I like to think it was Mackenzie, a practitioner of medicine, who coloured the physiology of Lewis to a human tint. However that may be, Lewis was not to be confined to the laboratory, but went to the out-patient department and the wards. He felt it natural that the scientific method should be applied to research in practical medicine, that medicine itself should be directed and developed by clinical science.

Thinkers are not common, and when a thinker is also a doer you have a rare combination. Meeting Lewis was not always easy, though later it became easier. His modesty could not hide the fact that he was indeed superior-a superman of a wholesome kind. He had a reserved manner in social contact, suggesting that his energy was concentrated so much on his life's work that little interest remained for casual visitors or acquaintances. With closer contact, however, anyone showing real interest and a willingness to be corrected, would not fail to receive help and encouragement. His standards were set high, personally and editorially. Did he not once reject for Heart a paper from Mackenzie, who took it in good part after the first shock?

As a writer of precise and lucid English, carefully adapted to scientific work, Lewis was also distinguished. He had something to explain or to tell, and he left no doubt as to his meaning. More remarkable is the fact that one man could so combine physiological knowledge with a grasp of the essentials of medical teaching and practice. His brief Diseases of the Heart is sufficient proof of this blend of scientist and clinician.

Our feeling about Sir Thomas Lewis might be expressed as gratitude and pride that we have had with us so great and so good a man who dedicated himself to the service of humanity, and chose the field of cardiology and of clinical science. 